\title{
Extra-Visceral Retroperitoneal Echinococcosis. Case Series with Follow-Up
}

\author{
Echinococosis Retroperitoneal Extra-Visceral. Serie de Casos con Seguimiento
}

\author{
Carlos Manterola ${ }^{1,2}$
}

MANTEROLA, C. Extra-visceral retroperitoneal echinococcosis. Case series with follow-up. Int. J. Morphol., 39(2):386-389, 2021.

SUMMARY: Extra-visceral retroperitoneal echinococcosis (EVRE), represents an infrequent condition, even in endemic areas. Its best treatment option is surgery. The aim of this study was to determine postoperative morbidity (POM) and recurrence in patients with EVRE, surgically treated. Case series with follow-up of patients with EVRE undergoing surgery consecutively at RedSalud Mayor Temuco Clinic, between 2008 and 2019. The outcome variables were POM and recurrence. Other variables of interest were cyst diameter, surgical time, and hospital stay. Descriptive statistics was used. In this study, 12 patients (75.0\% male), with a median age of 46 years, were treated. The $58.3 \%$ of cases were primary retroperitoneal cysts. The median of cyst diameter, surgical time, and hospital stay were $15 \mathrm{~cm}, 95 \mathrm{~min}$, and 4 days respectively. The most frequent type of resection was total cystectomy (58.3\%). MPO was $8.3 \%$ (there was urinary infection in one patient). No reoperations were necessary. There was no operative mortality. With a median follow-up of 90 months, a recurrence of $8.3 \%$ was verified (one case). The results achieved, in terms of POM and recurrence were similar to other series.

KEY WORDS: "Echinococcosis"[Mesh]; Hydatid cyst; "Retroperitoneum"[Mesh]; "Surgery"[Mesh].

\section{INTRODUCTION}

Extra-visceral retroperitoneal echinococcosis (EVRE) is a rare condition even in endemic areas, with an estimated prevalence less than $1 \%$ (Kafih et al., 1993; Subercaseaux et al., 2010; Yang et al., 2011; Guler et al., 2015; Tali et al., 2015; Jerraya et al., 2018).

Primary EVRE are even less frequent. As an example, Akbulut published an overview of cases between 2000 and 2010, in which one, only 41 cases collected from different databases (Akbulut et al., 2010).

One of the most frequently retroperitoneal structures parasitized in these cases is the psoas muscle (Kafih et al.; El Malki et al., 2007; Bedioui et al., 2008; Alaoui et al., 2016).

Differential diagnosis can be made with other tumors that can be located in the retroperitoneum, such as linfangioma and sarcomas, but only with the physical examination it is very difficult. Tomographic images allow defining the diagnosis, though preferentially in endemic areas of echinococcosis (Fig. 1) (Sall et al., 2010).
Surgery is the gold-standard therapy for EVRE, because allow the cyst excision (Subercaseaux et al.; Sall et al.; Sherwani et al., 2015). Other options have been described, such as PAIR and medical treatment, but the evidence that support it is low (Özkardes, et al., 2014).

The aim of this study was to determine postoperative morbidity (POM) and recurrence in patients with EVRE, surgically treated.

\section{MATERIAL AND METHOD}

The report of this study was written based on the MInCir Declaration for the reporting of descriptive observational studies (Manterola \& Otzen, 2017).

Study design: Case series with follow-up.

Setting: The study was conducted at Clínica RedSalud Mayor Temuco. The recruitment period was between January

\footnotetext{
${ }^{1}$ Department of Surgery and Center for Morphological and Surgical Studies (CEMyQ), Universidad de La Frontera, Temuco, Chile.

${ }^{2}$ Clínica RedSalud Mayor, Temuco, Chile.
} 
2008 and September 2019 (minimum follow-up was 15 months).

Participants: All patients with EVRE (not located in pancreas, kidneys, neither bladder), defined by WHO classification (Wang et al., 2003), consecutively undergoing surgery by the first author (CM), were included. Not exclusion criteria were considered.

Sample size: Since this is a descriptive study, no sample size was estimated. All patients with EVRE undergoing surgery in the period and institution indicated were considered.

Variables: Outcome variables were POM and recurrence. The latter measured up to 15 months after surgery; it was considered dichotomous (present or absent); severity was estimated applying the Clavien \& Dindo proposal (Clavien et al., 2009). Other variables of interest were age, sex, location, type of surgery, and operative mortality.

Follow-up protocol: After hospital discharge, all patients were followed up with strict controls at least at months 1,2 , 3 and 6; and after that once a year. During the controls, a clinical evaluation, general laboratory tests and computed tomography of the abdomen and pelvis were realized.
Statistical methods: Data collection was carried out and analyzed with the Stata 11.0 / SE® program. Descriptive statistics was used, applying measures of central tendency and dispersion (medians, minimum and maximum values).

Biases: These were reduced with a masked data collection and a complete follow-up of the patients that make up this series for at least 15 months (the last patient recruited).

Ethics: Ethical guidelines for research defined by the Declaration of Helsinki (World Medical Association, 2013), were observed. All patients gave their informed consent in writing.

\section{RESULTS}

During the study period, 12 patients were operated for EVRE. Age and body mass index median were of 46 years and $27.0 \mathrm{~kg} / \mathrm{m} 2$; and $75.0 \%$ of which were male. Median symptom time was 9 months; and $66.7 \%$ of the series had some type of comorbidity (Tables I and II).

From an ultrasonographic point of view, $66.7 \%$ of cases had type I cysts. On the other hand, $58.3 \%$ of cases Table I. Distribution of clinical variables in patients under study. $(\mathrm{N}=12)$

\begin{tabular}{lcc}
\hline Variable & $\mathrm{N}^{\circ}$ cases & $\%$ \\
\hline Sex & & \\
$\quad$ Male & 9 & 75.0 \\
$\quad$ Female & 3 & 25.0 \\
Locations & & \\
$\quad$ Exclusive retroperitoneal localization & 7 & 58.3 \\
$\quad$ Coexistence with other locations * & 5 & 41.7 \\
$\quad$ Abdominal and pelvic peritoneum & 3 & 25.0 \\
$\quad$ Greater omentum & 2 & 16.7 \\
Comorbidity & & \\
$\quad$ None & 4 & 33.4 \\
Arterial hypertension & 5 & 41.7 \\
$\quad$ Heart disease & 1 & 8.3 \\
Malnutrition & 1 & 8.3 \\
$\quad$ Pregnancv & 1 & 8.3 \\
Previous hydatid surgery ** & & \\
$\quad$ No & 7 & 58.3 \\
$\quad$ Yes & 5 & 41.7 \\
Ultrasonographical aspect (WHO) & & \\
$\quad$ Type I & 8 & 66.7 \\
$\quad$ Type II & 3 & 25.0 \\
$\quad$ Type III & 1 & 8.3 \\
Type of surgery & & \\
$\quad$ Total cystectomy & 7 & 58.3 \\
$\quad$ Subtotal cystectomy & 5 & 41.7 \\
\hline *: Other organs simultaneously involved. In all of these patients, total cystectomy of the \\
other cyst was realized. **: Previous liver hydatid surgery. & &
\end{tabular}
were primary retroperitoneum, in whom a total cystectomy was performed (Table I).

All of the primary lesions were located in the psoas muscle ( 7 cases; $58.3 \%$ ), in the other 5 cases the location of the cyst was unspecific (Table I and Fig. 1).

Total cystectomy was the most frequent procedure (Table I, Figs. 2 and 3).

The medians of cyst diameter, surgical time, and hospital stay were $15 \mathrm{~cm}, 95 \mathrm{~min}$, and 46 days respectively (Table II). No reoperations were necessary in any patient.

POM was $8.3 \%$ ( 1 case). It was a patient with urinary tract infection (Clavien \& Dindo type II). There was no operative mortality.

All specimens were sent to pathological study (Fig. 4).

With a median follow-up of 90 months, a recurrence of $8.3 \%$ (one case with peritoneal recurrence). It was diagnosed two years after surgery and operated one month later. 
Table II. Distribution of clinical variables in patients under study. $(\mathrm{N}=12)$

\begin{tabular}{lcc}
\hline Variable & Median & Minimum - Maximum \\
\hline Age (years) & 46 & $25-66$ \\
Body mass index $\left(\mathrm{kg} / \mathrm{m}^{2}\right)$ & 27 & $24.0-38.6$ \\
Symptom time $(\mathrm{months})$ & 9 & $6-12$ \\
Cyst diameter $(\mathrm{cm}) *$ & 15 & $8-21$ \\
Surgical time (min) & 95 & $55-125$ \\
Hospital stay (days) & 4 & $2-7$ \\
Follow-up (months) & 90 & $15-144$ \\
\hline
\end{tabular}

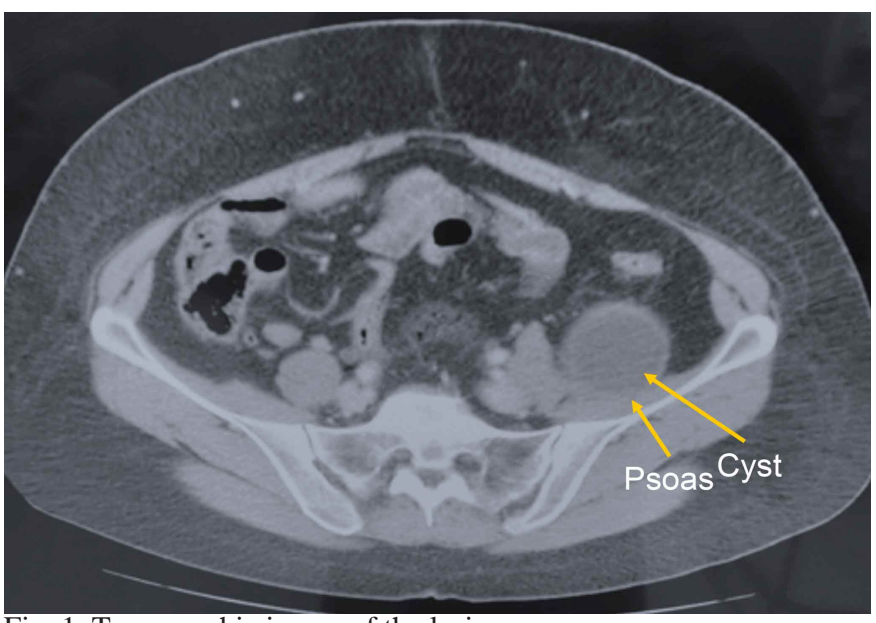

Fig. 1. Tomographic image of the lesion.
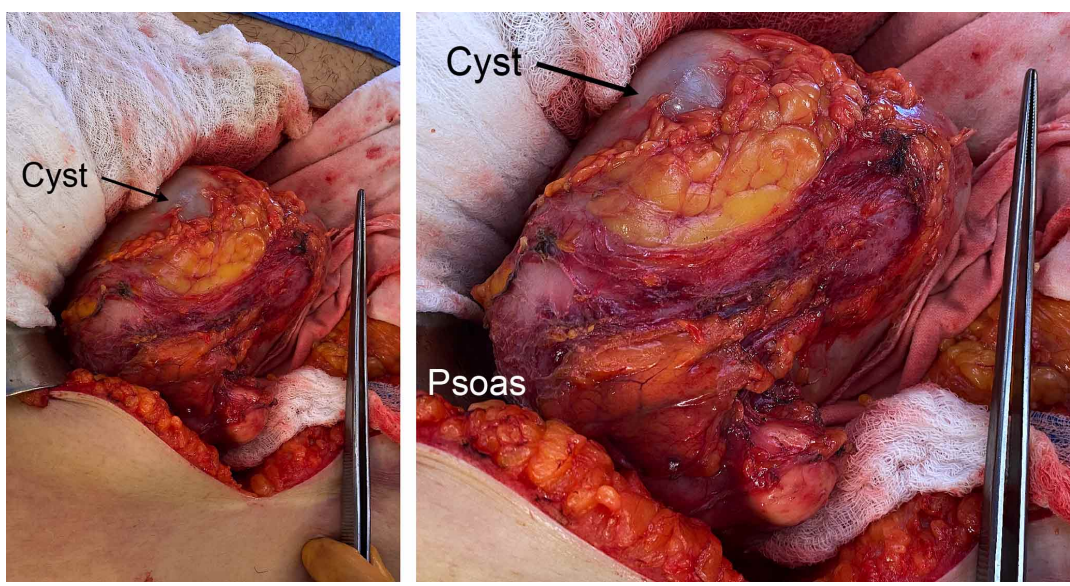

Fig. 2. Intraoperative view of the cyst.
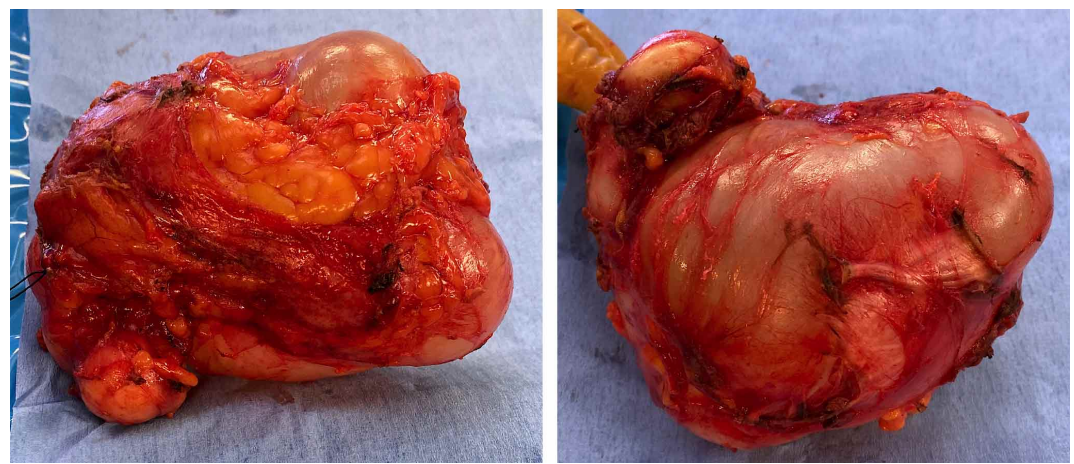

Fig. 3. Surgical specimen.

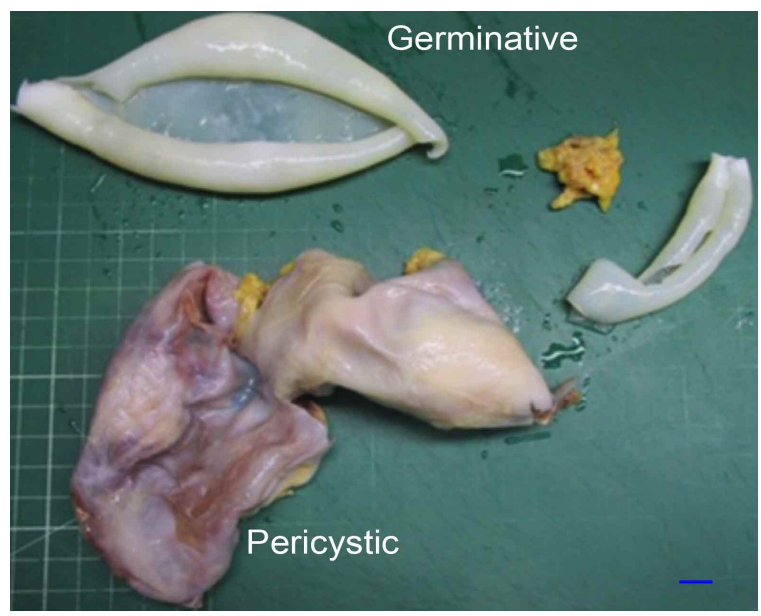

Fig. 4. Pathological study of the surgical piece. The germinal and pericystic layers can be seen.

\section{DISCUSSION}

Novelty of the proposal: The novelty of the proposal is that it is a singlecenter and regional casuistry of patients, with comparable results with other series (Angulo et al., 1998; Aydinli et al., 2007). On the other hand, the psoas muscle is a very uncommon location for hydatid cyst accounting for $1 \%$ of cases (Bedioui et al.).

Comment on observed results: If a cystic lesion is diagnosed in the retroperitoneum in a patient living in an area of endemic cystic echinococcosis, a differential diagnosis of cystic echinococcosis should be considered (Kafih et al.; Akbulut et al.). Surgery is essential in the treatment of EVRE and is considered curative when macroscopic disease is removed. 
In cases of hepatic or peritoneal hydatidosis, it is understood that the retroperitoneal location would be secondary. However, the pathogenesis of those primary cysts of the retroperitoneum could be explained by hematogenous dissemination (transition of the embryos from the hepatic and pulmonary filter), lymphatic (from the intestine), or migration through hemorrhoidal vessels of embryos that are kept in the rectum (Subercaseaux et al.).

Limitations of the study: It should be noted that this is a small series, in which all patients underwent surgery by the same surgeon. On the other hand, in the last cases, the followup is still brief.

By way of conclusion, it can be stated that the results verified in this series, in terms of POM, mortality and recurrence, are comparable to other studies.

MANTEROLA, C.Echinococosis retroperitoneal extra-visceral. Serie de casos con seguimiento. Int. J. Morphol., 39(2):386-389, 2021.

RESUMEN: La equinococosis retroperitoneal extravisceral (EREV), representa una condición poco frecuente, incluso en áreas endémicas. Su mejor opción de tratamiento es la cirugía. El objetivo de este estudio fue determinar morbilidad postoperatoria (MOP) y recurrencia de pacientes con EREV tratados quirúrgicamente. Serie de casos con seguimiento de pacientes con EREV intervenidos de forma consecutiva en Clínica RedSalud Mayor Temuco, entre 2008 y 2019. Las variables resultado fueron POM y recurrencia. Otras variables de interés fueron diámetro del quiste, tiempo quirúrgico y estancia hospitalaria. Se utilizó estadística descriptiva. Se trató a 12 pacientes (75,0 \% hombres), con una mediana de edad de 46 años. El 58,3\% de los casos fueron quistes retroperitoneales primarios. La mediana del diámetro del quiste, tiempo quirúrgico y estancia hospitalaria fueron $15 \mathrm{~cm}, 95 \mathrm{~min}$ y 4 días, respectivamente. El tipo de resección más frecuente fue la quistectomía total $(58,3 \%)$. La MPO fue $8,3 \%$ (infección urinaria en un paciente). No hubo reintervenciones ni mortalidad operatoria. Con una mediana de seguimiento de 90 meses, se verificó una recurrencia de 8,3\% (un caso). Los resultados obtenidos, en cuanto a MPO y recurrencia, son similares a otras series.

PALABRAS CLAVE: Echinococcosis; Quiste hidatídico; Hidatidosis; Retroperitoneo; Cirugía.

\section{REFERENCES}

Akbulut, S.; Senol, A.; Ekin, A.; Bakir, S.; Bayan, K. \& Dursun, M. Primary retroperitoneal hydatid cyst: report of 2 cases and review of 41 published cases. Int. Surg., 95(3):189-96, 2010.

Alaoui, I.; Hjoui, F.; Doumbia, M.; Aoufi, S. \& Lyagoubi, M. Hydatid cyst of the psoas muscle: about a case. Pan. Afr. Med. J., 24:302, 2016.

Angulo, J. C.; Escribano, J.; Diego, A. \& Sanchez-Chapado, M. Isolated retrovesical and extrarenal retroperitoneal hydatidosis: clinical study of 10 cases and literature review. J. Urol., 159(1):76-82, 1998.
Aydinli, B.; Ozturk, G.; Yalcin Polat, K.; Atamanalp, S. S.; Ozbey, I.; Onbas, O.; Akcay, M. N.; Balik, A. A. \& Guvendi, B. Extravisceral primary hydatid cyst of the retroperitoneum. A. N. Z. J. Surg., 77(6):455-59, 2007.

Bedioui, H.; Nouira, K.; Daghfous, A.; Ammous, A.; Ayari, H.; Rebai, W.; Chebbi, F.; Ksantini, R.; Fteriche, F.; Jouini, M.; et al. Primary hydatid cyst of the psoas muscle: description of 9 cases in Tunisia and review of the literature. Med. Trop. (Mars.), 68(3):261-6, 2008.

Clavien, P. A.; Barkun, J.; de Oliveira, M. L.; Vauthey, J. N.; Dindo, D.; Schulick, R. D.; de Santibañes, E.; Pekolj, J.; Slankamenac, K.; Bassi, C.; et al. The Clavien-Dindo classification of surgical complications: five-year experience. Ann. Surg., 250(2):187-96, 2009.

El Malki, H. O.; El Mejdoubi, Y.; Bouslami, B.; Mohsine, R.; Ifrine, L. \& Belkouchi, A. Hydatid cyst of the psoas muscle. Sante, 17(3):177-9, 2007.

Guler, I.; Kivrak, H. Y. \& Tolu, I. Primary retroperitoneal hydatid cyst. Am. J. Med. Sci., 350(6):e6, 2015.

Jerraya, H.; Nouira, R. \& Dziri, C. Giant primary hydatid cyst of retroperitoneum. A. N. Z. J. Surg., 88(6):647, 2018.

Kafih, M.; Ajbal, M.; Ridai, M.; Idrissi, H. \& Zerouali, O. Hydatid cyst of the psoas muscle. Ann. Gastroenterol. Hepatol. (Paris), 29(3):110-2, 1993.

Manterola, C. \& Otzen, T. Checklist for reporting results using observational descriptive studies as research designs: the MInCir Initiative. Int. J. Morphol., 35(1):72-6, 2017.

Özkardes, A. B.; Tokaç, M.; Yetis,ir, F.; Bozkurt, B. \& Kılıç, M. Retroperitoneal hydatid cyst simulating irreducible inguinal hernia: case report. J. Clin. Anal. Med., 5(3):243-5, 2014.

Sall, I.; Ali, A. A.; El Kaoui, H.; Bouchentouf, S. M.; El Hjouji, A.; El Fahssi, M.; Bounaim, A.; Zentar, A. \& Sair, K. Primary hydatid cyst of the retroperitoneum. Am. J. Surg., 199(2):e25-6, 2010.

Sherwani, A. Y.; Sarmast, A. H.; Malik, A. A.; Shah, M.; Q-Parray, F.; AWani, M. \& Dangroo, S. Primary retroperitoneal hydatid cyst: a rare case report. Acta Med. Iran., 53(7):448-51, 2015.

Subercaseaux, V. S.; Besa, C. C.; Burdiles, O. A.; Huete, G. A. \& Contreras, O. O. Retroperitoneal hydatid cyst: a common disease in a rare location. Rev. Chilena Infectol., 27(6):556-60, 2010.

Tali, S.; Aksu, A.; Bozdag, P. G. \& Bozdag, A. Primary retroperitoneal hydatid cyst. Turkiye Parazitol. Derg., 39(3):241-3, 2015.

Wang, Y.; Zhang, X.; Bartholomot, B.; Liu, B.; Luo, J.; Li, T.; Wen, X.; Zheng, H.; Zhou, H.; Wen, H.; et al. Classification, follow-up and recurrence of hepatic cystic echinococcosis using ultrasound images. Trans. R. Soc. Trop. Med. Hyg., 97(2):203-11, 2003.

World Medical Association. WMA Declaration of Helsinki - Ethical Principles for Medical Research Involving Human Subjects. Fortaleza, 64th WMA General Assembly, 2013. Available from: https:// www.wma.net/policies-post/wma-declaration-of-helsinki-ethicalprinciples-for-medical-research-involving-human-subjects

Yang, G.; Wang, X.; Mao, Y. \& Liu, W. Case report of primary retroperitoneal hydatid cyst. Parasitol. Int., 60(3):333-4, 2011.

\section{Corresponding author: \\ Dr. Carlos Manterola}

Department of Surgery and CEMyQ

Universidad de La Frontera

Temuco- CHILE

\section{E-mail: carlos.manterola@ufrontera.cl}

Received: 22-11-2020

Accepted: 29-12-2020 